\title{
Flipping the Aviation English class for distant learning: experience from the field
}

\author{
Oksana Pershukova ${ }^{1, *}$, Olga Matviyenko ${ }^{2}$, Oksana Vasiukovych $^{1}$, and Nina Nikolska ${ }^{3}$ \\ ${ }^{1}$ National Aviation University, 1 Liubomyra Huzara Ave., Kyiv, 03058, Ukraine) \\ ${ }^{2}$ National Linguistic University, 73 Velyka Vasylkivska Str., Kyiv, 03680, Ukraine \\ ${ }^{3}$ National University of Life and Environmental Sciences of Ukraine, 15 Heroiv Oborony Str., Kyiv, 03041, Ukraine
}

\begin{abstract}
This study is aimed to verify experimentally the efficiency of the flipped classroom approach using in the process of online teaching Aviation English at National Aviation University. It was conducted from September till December 2020. The research included two groups of students of the second year of study speciality: 272 'Aviation Transport'. The experiment employed mixed-method research in convergent design. In the context of the experiment testing to determine students' level of professional language communicative competence in English were conducted in September and December 2020 at the beginning and the end of the first term of the academic year 2020-2021. Testing revealed that students from the experimental group have better results in professional language competence development. A survey was conducted in the experimental group aimed to reveal students' impression from the flipped classroom approach using in distant learning. According to the results of the experiment, it was stated that students have mainly positive attitude to the experiment Advantages and disadvantages of the approach are identified. The conclusion was made that in the context of distance learning, the flipped lessons approach is acceptable for mastering the Aviation English course.
\end{abstract}

\section{Introduction}

\subsection{The problem statement}

Since early spring of 2019, the epidemiological situation in our country as well as in the whole world made traditional forms of education impossible. The disturbance caused by the COVID-19 pandemic is qualified by the United Nations Organization as the largest disruption of the education systems in history, affecting nearly 1,6 billion of learners in more than 190 countries and all continents [1]. The created conditions have exacerbated the need for distant on-line education at various educational levels in Ukraine, including classes of Aviation English at National Aviation University.

New language proficiency requirements implemented by the International Civil Aviation Organization (ICAO, 2004) were followed by several theoretical and practical measures to improve the Aviation English teaching process $[2,3]$. To prepare students for foreign language communication in their future professional field, the modern educational process at the university should take into account both, the trends in the development of science and technology and the requirements of society for the quality of educational services.

It is widely known, that foreign language acquisition requires time, practice and patience. For the last decades, learning strategies as a way to make language learning

*e-mail: pershoks@gmail.com more effective have become a field of research for many scholars [4-6]. Application in the educational process constructivist approach in which the individual is in the centre of the educational process makes the process of learning easier and more effective [7]. Purposeful use of information and communication technologies, as well as electronic means in the educational process, is one of the most effective ways to accomplish this task. Teachers aim to present a rich learning experience to the students and to create a more engaging and motivating classroom atmosphere [8, p. 29].

Flipping the classroom is an exciting topic in educational research of the last two decades [9-11]. But there is a lack of scholars' consensus on what exactly the 'Flipped' or 'Inverted Classroom' is, there is no single model for it and there is a limited amount of research on its effectiveness. The objective of our study is to experimentally verify the efficiency of the flipped classroom approach use in the process of online teaching Aviation English.

\subsection{Literature review}

Scholars are conceptualizing this educational phenomenon in different ways. 'It involves blending learning - a combination of face-to-face interaction in the classroom with distance learning' believe Santikarn \& Wichadee [12]. This point of view is mainly supported and developed by Arnold-Garza who stated 'This approach is a type of hybrid or blended learning as well as problem-based learn- 
ing, using active learning techniques and new technologies [13]. These ideas are prominently reinforced in this way 'This notion draws on such concepts as active learning, student engagement, hybrid course design, and course podcasting' [14]. These definitions are some extend confusing, but most scholars seem to agree that fundamental principles of the flipped philosophy and the main value of this approach are active learning and student-centred learning approaches that can lead to enhanced student engagement, motivation, and learning [15]. Let us review some of these definitions and try to gain insights into what the notion of 'flipping the classroom' means and consists of.

Now exist a large literature about this notion. Oxford dictionary defines flipped classroom as a method of teaching in which students study new material at home, for example with videos over the internet, and then discuss and practice it with teachers in class, instead of the usual method where teachers present new material in school and students practice at home [16].

Though a basic form of this approach was used for many years by instructors of humanity-based disciplines assigning text reading in advance of a class to conduct further text analysis in the class [17], chemistry teachers Jon Bergmann \& Aaron Sams, who began using recorded lectures in 2006, are recognized as flipped classroom developers. They define the flipping approach as 'flipping the attention away from the teacher and toward the learner... and leveraging educational tools to enhance the learning environment [15]. According to these scholars, in the educational process, the inversion is observed 'which is traditionally done in class now done at home, and that which is traditionally done as homework is now completed in class' ([18], as cited in [8, p. 29]).

Bishop \& Verleger defined the flipped classroom as 'an educational technique that consists of two parts: interactive group learning activities inside the classroom, and direct computer-based individual instruction outside the classroom' [19]. Supporting this idea, but determining it as an approach Brame indicates, that 'flipping the classroom involves students in knowledge acquisition of course material before a class section, typically through assigned reading or lecture videos, leaving class time for the integration of knowledge through the application, analysis or synthesis-based activities' [20]. Specialists from nonprofit membership Association EDUCAUSE (dedicated to instructional technology in higher education) define the flipped classroom as 'A pedagogical model in which the typical lecture and homework elements of a course are reversed'. The main characteristics are given in this way 'Short video lectures are viewed by students at home before the class session'. Such lectures are either created by the instructor and posted online or selected from an online repository and are often seen as the key ingredient in the flipped approach [14]. Lage \& Platt explain the essence of the approach of the flipped (inverted) classroom thoroughly: 'The events that have traditionally taken place inside the classroom now take place outside the classroom and vice versa. The researchers consider it the most acceptable for solving the problem of inconsistency of edu- cational styles possessing the students and the instructors and point out the opportunities of interaction as the main strength of the approach. Besides, they emphasize that this approach implementation makes it possible for facultystudents to clear up any confusion immediately, and the instructors can monitor students' performance and comprehension [21].

Many scholars $[8,13,17]$ stress the idea about an important role that modern technologies play in approach development. Creating educational video instructors can provide the lecture content and implement the flip taken from online resources. Among them are Khan Academy, Coursera, TED talks and even YouTube, providing access to recorded lectures, instructional videos, and other interactive elements [13] But, as Basal claims, that 'an $e d u$ cational video or video lecture is different from showing video in the classroom'. That is why video-content is integrated through the use of lecture capture technology such as Tegrity, Echo 360, Panopto, or iPad apps like Educreations and Doceri in 'concert with lecture slides for delivering course concepts' [17]. Subsequently, it is a modern technology used to produce, edit, and distribute learning information, which brings an innovative perspective to traditional lectures [8]. A successful flipped class involves more than just recording didactic content and sending it to students before a lesson. Classroom time is used for engaging in activities, discussing concepts, clarifying hardto-understand information, and investigating questions related to content $[8$, p. 29]. The particular value of flipped classroom lies in the existing possibility for students to stop the video and rewind it if necessary, for better understanding. Furthermore, prerecorded videos must be inseparably combined with in-class activities. Otherwise, class time prove ineffective and time-consuming [8, p. 33]. Among other advantages, there is one more positive aspect of the approach. It allows instructors easy and quick detecting errors in students understanding of the content and evaluates their performing [15].

Now exist a large literature about different models flipped or inverted classroom and various approaches to implement this technology suggested by researches and practitioners [22]. No single accepted model or approach has been established. The term 'flipped' or 'inverted classroom' or simply 'flip' is commonly used for any lesson with pre-recorded videos or as a variant new information can be given in any other form (slides, audio, podcasts, narrated presentations, videocasts with animation, screen captures, printed texts) [13].

The advantages of the approach are indicated analyzed in the literature. 'The flipped classroom helps students learn to correct misconceptions and organize their new knowledge such that it is more accessible for future use. The immediate feedback also helps students recognize and think about their own growing understanding' [20]. Further analysis allows noting the following. Flipping the classroom represents an approach to teaching and learning that focuses on student involvement [17] and increases student engagement [22]. This shifts instructions to a learnercentred model of learning and autonomy [23]. The approach offers flexible instructional time and creates a dy- 
namic and interactive learning engagement [22], it brings together individual-based education idea of constructivism and the technology [7]. Basal suggests dividing a flipped classroom into learning environments: outside and inside the classroom, which must be integrated into the model to be effective. The researcher suggests defining some steps. The first step for teachers is planning in detail what will happen in each environment. The second is selecting a variety of appropriate activities that address the needs of all learners according to students' learning styles. The third is to determine how to integrate tasks and activities in both environments. The fourth is to use a learning management system, connecting the outside and inside parts like a bridge and presenting all activities in an organized way [8, p. 33].

So, the above stated allows us to note, that a flipped classroom or inverted learning is an approach to teaching and learning with a special instructional strategy. The term is used when students gain first exposure to new information on the educational topic outside of class, they have presented it through pre-recorded lecture videos or other media and/or literature reading, receive instructions on content clarifications through homework, while in-class time is devoted to discussions, exercises, projects and supplementary explanations. This approach creates a suitable learning environment for learning foreign languages at different educational levels including the university level. Researchers and practitioners [7, 8, 12, 22-24] actively discuss various aspects of flipped classroom implementation into ELT (English Language Teaching), its advantages and disadvantages regarding students' and instructors' perceptions. The authors make the general conclusion about the positive influence of flipping the classroom approach on students' EFL learning process. Our special interest was aroused by Chinese researcher Zhang who analyzed Flipped Classroom approach application and Teaching Process Reengineering via Smart learning in Aviation college (higher vocational school) preparing flight attendants. The research showed that the re-engineered teaching process, which was focused on learner-centred instruction, could effectively enhance student engagement both in and out of class instruction [25].

\section{The study}

Forced to stay at home and aiming to enhance students' learning achievements we came to the idea to reverse the traditional model of a classroom and focus class time on students' understanding and language skills formation while in pre-class time students would be sent prerecorded educational information in a different format for self-mastery. A clear requirement was set: pre-recorded video information has to be integrated with in-class activities alongside other integrated elements of technology. In the work, we identified the steps.

Step 1. A detailed plan of work for in-class and out-ofclass activities according to the official university curriculum was made.
Step 2. Available resources were estimated, identified sources for obtaining new materials and ways to create their materials.

Step 3. A variety of appropriate activities that address the needs of all students was selected.

Step 4. A learning management system, connecting the outside and inside class time and including students' knowledge and skills assessment system was chosen.

Step 5. Research questions were determined.

Based on the above considerations, the current study aimed to find out answers to three research question:

Research question 1. To explore the concept of the flipped classroom in the process of ESP (Aviation English) in a technical university in distant learning.

Research question 2. To examine students' performance throughout a semester of distant learning in a traditional and flipped environment.

Research question 3. To identify students' impressions of Aviation English Course distant learning at National Aviation University.

The hypothesis of the current study: The introduction of the flipped classroom approach into the language ESP course (Aviation English) distant learning can help students to improve their performance.

In our work, we paid special attention to sending students pre-recorded educational information for selfmastery in good time. These materials were sent to students in a different format (slides, audio texts, podcasts, video narrated presentations, videocasts with animation, printed texts). In-class time was used for active and interactive methods (real-time discussion, dialogues, presentations, quizzes and so on).

\subsection{Participants}

The participants of our study were 41 students of the second year of study at the National Aviation University speciality: 272 'Aviation Transport'. At the time of research (the third semester of 2020-2021), English for Specific Purposes (ESP) lessons were part of their official university curriculum. According to the curriculum, two-hour classes were held distantly once a week. Out of 41 participants, 17 were females and 24 were males who were ranged from 17 to 19 years. Although the students were registered in two different groups (control and experimental) matched by English language proficiency level the research was conducted by the same teacher who followed the same procedure and used the same materials for questioning and evaluation students' achievements in learning. In the process of the experiment, there were used the same educational materials for developing practical language skills in various types of speech activity in professional and educational spheres as well as attention was paid to the improvement of already acquired vocabulary and grammar skills. It is worthy to stress that different 
approaches to learning students in control and experimental groups were used. Both groups were taught using the same educational course and teaching materials through distant learning. But students of the experimental group were taught using flipped lessons approach while teaching students of the control group a traditional educational approach was used.

Students' level of language competence was assessed in the control and experimental groups by the course teacher and her colleague at the beginning and the end of the first term of the academic year 2020-2021. According to the results of the test, the conclusion was made that students' level of language competence in both groups was miscellaneous. It was found out that at the beginning of the experiment 4 students in the control group and 3 students in the experimental group had a Pre-intermediate level of language competence, besides 1 student in the control group and 2 in the experimental had a rather low level of language competence defined as Elementary, which is not enough to master the course. They were suggested special training in grammar and language practice. Teachers actions: posted online short video lectures for students to view at home before the next class session to free-up the class time for active learning and problem-solving activities. We used previously recorded videos and added interactive elements. The total length of the videos was limited from 5 to 20 minutes. Educational videos were sent to students via the system of corporate mail of National Aviation University at least three days before the class. Online classes took place through the system of corporate classroom.

\subsection{Methods}

During the experiment preparation, we used the ideas expressed by the scientists, whose papers we analyzed in the chapter Literature review in our interpretation. Prerecorded video information was integrated with in-class activities alongside other integrated elements of technology. Learning lectures were put under the control of the students, so they could be viewed more than once, practically as many times as necessary, while class time was devoted to the application of concepts learned through the lecture. A pre-class quiz on the lecture material was used systematically. During the study, students were suggested active and interactive learning exercises, performed language quizzes/tests, at the end of the semester they presented a project on one of the mastered topics.

To use mixed-method research in convergent design [26, pp. 3-6] we collected quantitative (language performance results) and qualitative (questionnaire answers) datasets. Next, we merged the results of the two data analyses to compare and validate one set of results with the other. Then we integrated information for better understanding the problem of using flipped classroom in ESP class (Aviation English) through online (distant) learning.

\subsection{Results and discussion}

The data analysis collected during the experiment suggests that the results of the testing at the beginning of the term showed nearly the same level of language competence in the experimental and control groups. The tests were assessed using the ECTS grading scale which split into five segments: A - 100-90; B - 89-82; C - 81-75; D - 7467; E - 66-60. According to the results, before the experiment, the percentage of students in the experimental group with a sufficient level of language competence before the experiment put 76,2\%. Consequently, 38,1\% of students of the experimental group had A-marks. After the experiment, the percentage of students with A-marks increased to $52,4 \%$. The difference reached $14,3 \%$. The percentage of students with $\mathrm{B}$ marks equalled $38,1 \%$ before, and $42,9 \%$ after the experiment, the decrease constituting $4,8 \%$. Consequently, the percentage of students in the experimental group with $\mathrm{C}$ and $\mathrm{D}$ marks, which indicated an insufficient level of professional language competence development, decreased sufficiently $\mathrm{C}$ from $14,3 \%$ to $4,8 \%$ with a difference of $-9,5 \%$, and $\mathrm{D}$ from $9,5 \%$ to $0 \%$. The total decrease of students with a low level of language competence is $19,0 \%$. While the total increase in students' success is $19,1 \%$. In the control group, the sufficient level before the experiment put $75 \%$, which was almost equal to the score in the experimental group $(76,1 \%)$. But, according to the results of the experiment, the differences in the levels of students' language competence positive changes are not so significant - only $5 \%$ (75\% vs $80 \%)$. The decrease in the number of students with an insufficient level of language competence: $\mathrm{C}-20 \%$ before the experiment and $20 \%$ after the experiment, was less significant compared to the experimental group. Besides, students with a mark D score of $5 \%$ before vs $0 \%$ after the experiment. The results of the testing are summarized in table 1. Students from the experimental group have better results in professional language competence development (experimental $+19,1 \%$ vs control $+5 \%$ ).

Research question 2. Students' performance before and after the experiment proves that the flipped classroom approach application had a positive effect on students' level of communicative competence.

To identify students' impressions of Aviation English Course distant learning in National Aviation University students of the experimental group were suggested to answer anonymously the questionnaire at the end of the first term (qualitative data). A Likert scale containing 5 ready answers (strongly agree - agree - neutral - disagree strongly disagree) was used to measure students' motivation for research question 3. The questionnaire was composed of 7 questions with possible responses which were scored using a rating scale of 1 to 5 . (5 corresponded to 'strongly agree' and 1 - 'strongly disagree'). The survey also included open-ended questions. They are presented in table 2).

Participating students were asked to discuss their experience with the flipped classroom in which they were engaged. Specifically, they were asked to explain their attitude to the approach. Students Feedback on the openended questions about Flipped classroom approach is presented here.

Question 1. What is your attitude to education from home? 
Table 1. Results of the testing the level of language competence before and after the experiment, quantitative data

\begin{tabular}{|c|c|c|c|c|c|c|c|c|c|c|}
\hline \multirow{3}{*}{ Marks } & \multicolumn{5}{|l|}{ Control } & \multicolumn{5}{|c|}{ Experimental } \\
\hline & \multicolumn{2}{|c|}{ Before the experiment } & \multicolumn{2}{|c|}{ After the experiment } & \multirow{2}{*}{$\begin{array}{l}\text { Difference } \\
\%\end{array}$} & \multicolumn{2}{|c|}{ Before the experiment } & \multicolumn{2}{|c|}{ After the experiment } & \multirow[t]{2}{*}{ Difference } \\
\hline & Students & $\%$ & Students & $\%$ & & Students & $\%$ & Students & $\%$ & \\
\hline A & 9 & 45 & 10 & 50 & 5 & 8 & 38,1 & 11 & 52,4 & 14,3 \\
\hline B & 6 & 30 & 6 & 30 & - & 8 & 38.1 & 9 & 42,9 & 4,8 \\
\hline $\mathrm{C}$ & 4 & 20 & 4 & 20 & - & 3 & 14,3 & 1 & 4,8 & $-9,5$ \\
\hline $\mathrm{D}$ & 1 & 5 & 0 & - & -5 & 2 & 9,5 & 0 & - & $-9,5$ \\
\hline Total & 20 & 100 & 20 & 100 & & 21 & 100 & 21 & 100 & \\
\hline
\end{tabular}

Table 2. Students' impressions of Aviation English Course distant learning

\begin{tabular}{|c|c|c|c|c|c|c|}
\hline No & Questions & $\begin{array}{l}\text { Strongly } \\
\text { agree (5) }\end{array}$ & $\begin{array}{l}\text { Agree } \\
(4)\end{array}$ & $\begin{array}{l}\text { Neutral } \\
\text { (3) }\end{array}$ & $\begin{array}{l}\text { Disagree } \\
\text { (2) }\end{array}$ & $\begin{array}{l}\text { Strongly } \\
\text { disagree (1) }\end{array}$ \\
\hline 1 & $\begin{array}{l}\text { I like the pre-class exposure of information } \\
\text { (reading the coursebook, watching video lec- } \\
\text { tures, podcasts or screencasts or listening to } \\
\text { audio information). It contributed to learning } \\
\text { the language connected with future professional } \\
\text { communicative activity. }\end{array}$ & 4 & 14 & 2 & 1 & 0 \\
\hline 2 & $\begin{array}{l}\text { The incentive to come to class prepared was use- } \\
\text { ful because we had to complete an online quiz } \\
\text { or take part in the debate/discussion associated } \\
\text { with the assignment. It helped me to understand } \\
\text { and master the learning content better. }\end{array}$ & 7 & 9 & 5 & 0 & 0 \\
\hline 3 & $\begin{array}{l}\text { Pre-class exposure of information (reading the } \\
\text { coursebook, video lectures, podcasts or screen- } \\
\text { casts or listening to audio information) encour- } \\
\text { aged me to discuss the course content with my } \\
\text { peers. }\end{array}$ & 2 & 2 & 11 & 4 & 2 \\
\hline 4 & $\begin{array}{l}\text { I'm sure that pre-class exposure of information } \\
\text { (reading the coursebook, video lectures, pod- } \\
\text { casts or screencasts or listening to audio infor- } \\
\text { mation) helped me to focus on the most impor- } \\
\text { tant aspects of the course. }\end{array}$ & 3 & 14 & 2 & 1 & 0 \\
\hline 5 & $\begin{array}{l}\text { Pre-class exposure and asynchronously delivery } \\
\text { of information made it possible for me to study } \\
\text { in a convenient place and time and I could repeat } \\
\text { it as many times as needed at my own pace. }\end{array}$ & 15 & 3 & 3 & 0 & 0 \\
\hline 6 & $\begin{array}{l}\text { Online short quizzes, discussions and debates } \\
\text { served as informal checks of content under- } \\
\text { standing. I was actively engaged with pre-class } \\
\text { video lectures, printed and audio information } \\
\text { sent through email. }\end{array}$ & 12 & 5 & 2 & 2 & 0 \\
\hline 7 & $\begin{array}{l}\text { Active engagement in mastering pre-class infor- } \\
\text { mation and in in- class activities participation } \\
\text { helped me to prepare the project at the end of } \\
\text { the semester and successfully pass the midterm } \\
\text { exam. }\end{array}$ & 10 & 7 & 2 & 1 & 1 \\
\hline & Total & 53 & 53 & 27 & 9 & 3 \\
\hline
\end{tabular}

Positive -16 .

Negative -3 .

Neutral -2.

Students explained negative answers: 'It was cool at the beginning, but now ... it is not, especially when you have technical problems with computer or telephone because it isn't new or internet is not good enough. I miss my friends and instructors', 'Constant communication through the screen... I find it difficult'.
Question 2. Do you consider flipping the classroom the best approach to learning in a pandemic situation?

Positive -15 .
Negative -1 .
Neutral -5

The common answers: 'It is good, but I can't call it the best'. 'I like the approach. But I feel it is a little time consuming because I have to watch the video or listen to 
the audio assignment and then we do different activities in class. It's like double the amount'.

Question 3. Would you like to be taught ESP traditionally or using flipped classroom in future?

Positive - 15.

Negative -3 .

Neutral -3.

The most common answer: 'I like the approach very much, previewed lectures were interesting, they were authentic and connected with my future profession, they widened my world view. I had plenty of time to watch them'. Among the answers, there are three answers with the meaning ' $\mathrm{I}$ would prefer to mix the different approaches'.

Question 4. What recommendations would you give to other teachers using the flipped classroom approach for teaching ESP online?

Left without answers.

Question 5. Do you have any other comments or questions? Left without answers.

Research question 3. To identify students' impressions of Aviation English Course distant learning at National Aviation University. The data collected during the experiment are presented in table 2 , it reveals that students positively evaluated the application of the approach 'Strongly agree' and 'Agree' both received 53 balls. The highest scores of students' answers were given to Q 1 and Q 5 - 'Strongly agree' and 'Agree' - 18 balls. It indicates increasing students' motivation to study through selfmastery of content at home. Besides we can comment on it in this way: students' like taking responsibility for their study and appreciate the way to individualize the way of learning. The possibility to check the content understanding (Q 6) together with the realized opportunity to receive a high mark for the work done (Q 7) as well as opportunities to focus on the most important aspects of the course (Q 4) also were highly approved by the students and received 17 balls. High enough students evaluated the incentive to come to class prepared (Q 2). This question scored 16 balls. The less score received Q 3, which indicates a reluctance to share impressions about learning for some reason. The total of positive answers is 106 , while the total of negative answers is 12 and neutral 27. Students answers to open-ended questions allow us to conclude that the stressful situation affected all aspects of our life, it also displayed in the educational sphere. Students are mainly positive about the flipped classroom approach. They especially appreciate asynchronously delivering or pre-class exposure of information which flipped classroom is characterized.

Research question 1. To explore the concept of the flipped classroom in the process of ESP in technical university distant learning. The results of the analyses allow us to state that the concept 'flipped classroom in the process of distant ESP learning in technical university' provides the following. Students gain first exposure to new information on the educational topic outside of class, they have presented it through pre-recorded lecture videos or other media and/or literature reading, receive instructions on content clarifications through homework, while in-class time is devoted to language practice, discussions, exercises, projects and supplementary explanations. The main features of the approach are: frees time for classroom work; creates conditions for individualization of professional language learning; puts more responsibility for learning on the students; promotes the development of language and speech skills; allows to provide a professional orientation of educational texts and work on them in four types of speech activity; teachers function mainly as advisors, encouraging students in their work.

Results of the experiment revealed a positive effect of the approach application. Students of the flipped environment scored significantly higher on language tests compared to the students of traditional approach distant learning. However, this approach is teacher's time-consuming and not suitable for all students due to some constraints. Several students indicated problems existing in learning caused by technical problems with the computers, internet and electricity (obsolete equipment caused connection failure especially in rural areas). Some students indicated a preference for the in-class lecture. So, it should not be the only method used under normal conditions.

\section{Conclusions}

Extreme transition to distance learning has created problems due to insufficient technical equipment, teachers and students' unpreparedness to work in new conditions caused by lack of training. At the same time, the new learning format has provided a wide range of opportunities and prospects for change and improvement. Technologically enriched learning environments in modern university in the appropriate format offered students from experimental group better learning opportunities. Correctly selected course materials, meeting the educational goals ensured a positive learning income objective. It is proved by the results of the experiment. Students from the experimental group have better results in professional language competence development than students from the control group (experimental $+19,1 \%$ vs control $+5 \%$ ).

Results of the questionnaire reveal that students positively evaluated the application of the approach (positive answers are 106, while the total of negative increasing students' motivation to study through self-mastery of content at home; taking responsibility for their answers is 12 and neutral - 27). Opportunities offered by approach (asynchronously delivering of information; study and appreciate the way to individualize the way of learning; possibility to check the content understanding; realized opportunity to receive a high mark for the work done; focusing on the most important aspects of the course) are approved by the students.

As a result of the experiment, we concluded that for the successful implementation of distance learning, the instructor of a technical educational institution has to be ready to use active and interactive teaching methods; to promote the formation of students' learning style to work online; to master the capabilities of the online learning platform and the necessary software. To manage the course effectively, the instructor should develop students' 
skills to stick to deadlines use tools for students' encouragement to assess students' paper on time. We have to admit some downsides of the approach. The model of flipping the class should be explained to students beforehand, nevertheless, some of them can feel uncomfortable and lose much time and efforts. Besides, this approach is the instructor's time and efforts consuming, especially the process of learning information searching, adopting and lectures recording, furthermore the instructor must be skilled enough.

We identify the flipped classroom approach as a highly successful educational practice, giving opportunities to personalize instruction and allows students to be more responsible for their learning. Students can master language skills formation at their own pace, which gives them opportunities to become comfortable with the learning material. In the context of distance learning, the flipped lessons approach is acceptable for mastering the Aviation English course. We believe that foreign colleagues' experience in this approach application deserves a comprehensive study.

\section{References}

[1] Education during COVID-19 and beyond. Policy Brief. United Nations Executive Summary, https://www.un.org/development/desa/ $\mathrm{dspd} / \mathrm{wp}$-content/uploads/sites/22/ $2020 / 08 /$ sg_policy_brief_covid-19_and_ education_august_2020.pdf

[2] Guidelines for Aviation English Training Programs, International Civil Aviation Organization, Montreal (2009)

[3] Manual on the Implementation of ICAO Language Proficiency Requirement, International Civil Aviation Organization, Montreal, 2nd edn. (2010)

[4] R. Oxford, Language Learning Strategies: What Every Teacher Should Know (Newbury House Publisher, 1990), ISBN 9780066326078

[5] A. Hardan, 4th International Conference on New Horizons in Education 106, 1712 (2013)

[6] M. Lessard-Clouston, The Internet TESL Journal 3, 1 (1997)

[7] S. Boyraz, G. Ocak, Journal of Language and Linguistics Studies 13, 426 (2017)

[8] A. Başal, Turkish Online Journal of Distance Education 16, 28 (2015)

[9] O. Glazunova, T. Voloshyna, V. Korolchuk, O. Parhomenko, E3S Web of Conferences 166, 10014 (2020)

[10] T. Hodovaniuk, T. Makhometa, I. Tiahai, M. Medvedieva, S. Pryshchepa, CEUR Workshop Proceedings 2732, 709 (2020)
[11] O. Klochko, V. Fedorets, S. Tkachenko, O. Maliar, CEUR Workshop Proceedings 2732, 1233 (2020)

[12] B. Santikarn, S. Wichadee, International Journal of Emerging Technologies in Learning 13, 123 (2018)

[13] S. Arnold-Garza, Communications in Information Literacy 8, 7 (2014)

[14] 7 things you should know about flipped classroom (2012), https://library.educause.edu/-/ media/files/library/2012/2/eli7081-pdf

[15] Flipped classroom trends: A survey of college faculty (special report) (2015), https://wwW. facultyfocus.com/wp-content/uploads/ images/Flipped-Classroom-Trends_ FF-Report-2015.pdf

[16] Oxford dictionary (2020), https://www. oxfordlearnersdictionaries.com/ definition/english/flipped-classroom

[17] S. Mccallum, J. Schultz, K. Sellke, J. Spartz, International journal of teaching and Learning in Higher Education 27, 42 (2015)

[18] J. Bergmann, A. Sams, Flip Your Classroom: Reach Every Student in Every Class Every Day, Flipped Learning Series (International Society for Technology in Education, 2012), ISBN 9781564843159, https://www. academia.edu/ 30809767/_Jonathan_Bergmann_Aaron_Sams_ Flip_Your_Classroo_BookZZ_org

[19] J. Bishop, M. Verleger, The flipped classroom: A survey of the research, in ASEE Annual Conference and Exposition, Conference Proceedings (2013), pp. 118

[20] B. Brame, Flipping the classroom (2013), http: //cft.vanderbilt.edu/guides-sub-pages/ flipping-the-classroom/

[21] M.J. Lage, G.J. Platt, M. Treglia, The Journal of Economic Education 31, 30 (2000)

[22] Z. Turan, B. Akdag-Cimen, Computer Assisted Language Learning 33, 590 (2020)

[23] A. Mohammad, Innovation in Language Learning and Teaching 13, 1 (2017)

[24] X. Dong, Creative Education 07, 1335 (2016)

[25] Z. Zhang, A Practical Research on the Flipped Classroom and Teaching Process Reengineering via Smart Learning, in Proceedings of the 2019 5th International Conference on Social Science and Higher Education (ICSSHE 2019) (Atlantis Press, 2019/08), pp. 210-214, ISBN 978-94-6252-772-0, ISSN 2352-5398, https://download.atlantis-press.com/ proceedings/icsshe-19/125915871

[26] J.W. Creswell, A.L. Garrett, South African Journal of Education 28, 321 (2008) 